\title{
Trends in snowmelt-related streamflow timing in the conterminous United States
}

R.W. Dudley*¹, G.A. Hodgkins ${ }^{1}$, M.R. McHale ${ }^{2}$, M.J. Kolian ${ }^{3}$, and B. Renard ${ }^{4}$

* Corresponding author: U.S. Geological Survey, New England Water Science Center, 196 Whitten Road, Augusta, ME, USA 04330, rwdudley@usgs.gov

\footnotetext{
${ }^{1}$ U.S. Geological Survey, New England Water Science Center, 196 Whitten Road, Augusta, ME, 04330

${ }^{2}$ U.S. Geological Survey, New York Water Science Center, 425 Jordan Road, Troy, NY, 12180

${ }^{3}$ U.S. Environmental Protection Agency, Office of Atmospheric Programs, 1200 Pennsylvania Avenue, N.W., Washington, DC, 20460

${ }^{4}$ Irstea, Hydrology-Hydraulics, Lyon, France
} 


\section{Abstract}

Changes in snowmelt-related streamflow timing have implications for water availability and use as well as ecologically relevant shifts in streamflow. Historical trends in snowmelt-related streamflow timing (winter-spring center volume date, WSCVD) were computed for minimally disturbed river basins in the conterminous United States. WSCVD was computed by summing daily streamflow for a seasonal window then calculating the day that half of the seasonal volume had flowed past the gage. We used basins where at least 30 percent of annual precipitation was received as snow, and streamflow data were restricted to regionally based winter-spring periods to focus the analyses on snowmelt-related streamflow. Trends over time in WSCVD at gages in the eastern U.S. were relatively homogenous in magnitude and direction and statistically significant; median WSCVD was earlier by 8.2 days (1.1 days/decade) and 8.6 days (1.6 days/decade) for 1940-2014 and 1960-2014 periods respectively. Fewer trends in the West were significant though most trends indicated earlier WSCVD over time. Trends at low-to-mid elevation $(<1,600 \mathrm{~m})$ basins in the West, predominantly located in the Northwest, had median earlier WSCVD by 6.8 days (1940-2014, 0.9 days/decade) and 3.4 days (1960-2014, 0.6 days/decade). Streamflow timing at high-elevation $(\geq 1,600 \mathrm{~m})$ basins in the West had median earlier WSCVD by 4.0 days (1940-2014, 0.5 days/decade) and 5.2 days (1960-2014, 0.9 days/decade). Trends toward earlier WSCVD in the Northwest were not statistically significant, differing from previous studies that observed many large and (or) significant trends in this region. Much of this difference is likely due to the sensitivity of trend tests to the time period being tested, as well as differences in the streamflow timing metrics used among the studies. Mean February-May air temperature was significantly correlated with WSCVD at 100 percent of the study gages (field significant, $\mathrm{p}<0.0001$ ), demonstrating the sensitivity of WSCVD to air 
temperature across snowmelt dominated basins in the U.S. WSCVD in high elevation basins in the West, however, was related to both air temperature and precipitation yielding earlier snowmelt-related streamflow timing under warmer and drier conditions.

(KEY TERMS: snowmelt, streamflow, trends, climate, hydrology) 


\section{Introduction}

\subsection{Importance of Snowmelt-Related Streamflow Timing}

The timing of snowmelt-related streamflow is as important as the overall quantity and quality of water, for both ecosystem health and human uses (Dettinger and Cayan, 1995). Where snowmelt is a substantial fraction of available water, earlier melt and runoff can decrease water availability later in the year, impacting agriculture, ecosystems, and frequency and occurrence of wildfires (Hall et al., 2015). Westerling et al. (2016) attributed significant increases in the frequency of large wildfires in the Northern Rocky Mountains and Pacific Northwest over recent decades to changes in moisture deficit associated with snowmelt-related streamflow timing-computed as the date of the center of mass of annual streamflow (CTI) at snowmelt-dominated basins. During 1970-2012, the earliest third of CTI values were associated with 70\% of the total area burned by large forest fires, and 43\% of the total area burned in non-forest fires (Westerling, 2016).

As much as 75 percent of water supplies in the western United States are derived from snowmelt (Dettinger, 2005). It is estimated that by 2050, future climate-change related warming will have a substantial impact on water supply in the western U.S because of a large reduction of snowpack (natural storage) and earlier spring peak streamflow (Barnett et al. 2005). Stewart et al. (2004) estimated that snowmelt-related streamflow timing in western North America during 2040-2059 may be about two to four weeks earlier relative to a 1951-1980 reference period. Roy et al. (2012) anticipated that approximately one-third of counties will be at high or extreme risk of water shortages by the year 2050 on the basis of estimated future water use and climate conditions. Concerns include whether reservoir storage in most of the western U.S. is adequate to handle the earlier peak streamflow and meet competing water use interests-for example hydropower generation vs. federally protected salmon in the Northwest (Barnett et al., 2005). 
In the eastern United States, impacts of earlier snowmelt-related streamflow timing are less clear, as snowmelt is normally complete by May and summer rainfall generally is abundant (Hodgkins and Dudley, 2006). Spring peak flows in the Northeast are projected to become earlier by about a week by mid-century relative to a 1961-1990 reference period (Hayhoe et al., 2007). Changes in snowmelt-related streamflow timing may be important though, for example, if peak spring migration of the endangered Atlantic salmon (which is partially dependent on flow) becomes out of phase with optimal environmental conditions, salmon survival could drop substantially (McCormick et al., 1998).

\subsection{Trends in Snowmelt-Related Streamflow Timing}

Climate-change indicators of snowmelt-related streamflow provide means for improved understanding of temperature-related effects on streamflow. Air temperatures in the United States during the past century have been related to observed changes in snow-to-rain ratios, snowpack, and timing of snowmelt-related streamflow (Regonda et al., 2005; Stewart et al., 2005; McCabe and Clark, 2005; Hodgkins and Dudley, 2006). Historical trends in the timing of snowmelt-related streamflow have been well studied, particularly in the western United States, where several studies have analyzed a large number of basins for most of the second half of the 20th century (Aguado et al., 1992; Cayan et al., 2001; Regonda et al., 2005; Stewart et al., 2005; McCabe and Clark, 2005; Westerling et al., 2006; Fritze et al., 2011; U.S. Environmental Protection Agency, 2014; Westerling, 2016). Other studies in the West have analyzed streamflow timing for specific regions (Dettinger and Cayan, 1995; Clow, 2010; Clark, 2010; Pederson et al., 2011). In the eastern United States, studies have covered extensive geographic areas (Hodgkins and Dudley, 2006; U.S. Environmental Protection Agency, 2014) and more 
specific regions (Hodgkins et al. 2003; Burns et al., 2007). Ryberg et al. (2015) studied many basins in the north-central U.S.

In the western U.S., there were widespread changes during the second half of the 20th Century toward earlier snowmelt-related streamflow timing, and very few basins with significantly later streamflow timing in the West (Regonda et al., 2005; Stewart et al., 2005; McCabe and Clark, 2005; Fritze et al., 2011). The highest number of significant changes were in the Northwest; many basins had non-significant trends in the interior West. Regonda et al. (2005) found 10-20 day changes toward earlier snowmelt-related streamflow timing during 1950-1999 to be common for basins under 2,500 $\mathrm{m}$ in elevation and little consistent change for basins over 2,500 m; McCabe and Clark (2005) also found that streamflow-timing trends were significantly related to elevation. In the eastern U.S., there were widespread changes toward earlier timing of snowmeltrelated streamflow north of $44^{\circ}$ North latitude, with the highest number of significant changes in northern New England (Hodgkins and Dudley, 2006).

Stewart et al. (2005) observed significant negative correlations (generally $-0.8 \leq r \leq-0.3$ ) between spring air temperatures and snowmelt-related streamflow timing at basins throughout the western U.S. (warmer temperatures associated with earlier dates). The correlations between streamflow timing and temperature were largely unchanged when the variance related to precipitation was removed. Streamflow timing was positively correlated with total winter precipitation in most of the West (more precipitation associated with later dates), and negatively correlated in parts of the Northwest and Southwest (Stewart et al., 2005).

Regonda et al. (2005) documented significantly earlier spring warm spells and increased precipitation over much of the western U.S. Decreases in winter precipitation in the Northwest combined with increases in spring temperatures appeared to have had a strong impact on 
snowmelt-related streamflow timing. Increased winter precipitation in the interior West may have offset increased air temperature and led to fewer or smaller changes in the timing of snowmelt-related streamflow. Regonda et al. (2005) also found that changes in snowpack water equivalent in the western U.S. are sensitive to the effects of temperature, but primarily in basins below about $2,500 \mathrm{~m}$.

In the eastern U.S., Hodgkins et al. (2003) found that air temperatures had much higher correlations with New England snowmelt-related streamflow timing than precipitation. The highest correlation with seasonal air temperatures was with March-April temperatures $(r=-0.72)$ while the highest correlation with precipitation was with January precipitation $(\mathrm{r}=-0.37)$.

Temperatures across the U.S. have increased overall by $0.7^{\circ} \mathrm{C}$ to $1.1^{\circ} \mathrm{C}$ since 1895 (Karl et al., 2009; Menne et al., 2010; Vose et al., 2012; Williams et al., 2012). Over this same period, average annual precipitation over the U.S. has increased by roughly 5 percent. This overall increase reflects, in part, a relatively dry early half of the record due to the major droughts of the 1930s and 1950s. Regionally, precipitation since 1991 (relative to 1901-1960) increased the most in the Northeast ( 8 percent), Midwest (9 percent), and southern Great Plains ( 8 percent), while much of the Southeast and Southwest had a mix of areas of increases and decreases (McRoberts and Nielsen-Gammon, 2011; Peterson et al., 2013).

Several regional studies have documented decreasing annual and seasonal ratios of snowfall to precipitation in the U.S. (Knowles et al., 2006; Feng and Hu, 2007; Huntington et al., 2004), and total snowfall has decreased in many parts of the U.S. based on widespread observations since 1930 (Kunkel et al., 2009). Studies have shown that snowpack over the past half century declined in most of the mountainous western U.S. concurrent with higher winter and spring air temperatures. Mote et al. (2005) reported that climate trends are the dominant factor in 
widespread declines in spring snowpack in the western U.S. during 1950-97. Hamlet et al. (2005) found most of the change in spring snowpack in the Rocky Mountains was attributed to increasing air temperatures rather than changes in precipitation, which were relatively small.

Much of the climate variability in the western U.S. is driven by Pacific climate patterns and snowmelt-related streamflow timing has a significant negative correlation with the Pacific Decadal Oscillation (PDO) for many basins (Stewart et al., 2005). Streamflow timing had a significant positive association with the Southern Oscillation Index for some basins in the Northwest and a significant negative association for many basins in the southwestern U.S. from 1948 to 2002 (Stewart et al., 2005). McCabe and Clark (2005) found a modest but significant relation between snowmelt-related streamflow timing and PDO and a weaker but still significant relation with Niño-3.4 sea-surface temperatures (region in the equatorial Pacific Ocean bounded by $5^{\circ}$ North $-5^{\circ}$ South and $170-120^{\circ}$ West), indicating that PDO and El-Niño Southern Oscillation (ENSO) account for a small part of streamflow timing variability. We know of no published work on the relation between large-scale climate patterns and eastern U.S. snowmeltrelated streamflow timing.

\subsection{Objectives of this paper}

We present a nationwide analysis of historical trends in snowmelt-related streamflow timing for the United States and use streamflow data through 2014; this provides more years of recent data than previous studies that cover large areas of the western or eastern U.S. Historical periods 1920-, 1940-, and 1960-2014 were studied, though most discussion of results focus on the 1940-, and 1960-2014 periods because they had the greatest number of stations available for analysis. To focus on snowmelt-related changes, we only use basins where at least 30 percent of annual precipitation falls in the form of snow and we restrict use of streamflow data to the 
winter-spring period to minimize the influence of other high-streamflow generating processes while including as much snowmelt-related streamflow as possible. We analyze historical trends considering the importance of assumptions of short and long-term persistence in structure of the data. We then look at the interannual correlation between snowmelt-related streamflow timing and air temperature, precipitation, winter-spring streamflow volume and ocean-atmosphere indices to help explain and provide context for the trends.

\section{Data and Methods}

\subsection{Streamflow data}

Daily mean streamflow data from U.S. Geological Survey (USGS) stream gages on river basins in the conterminous U.S. were used in this study. Stream gages selected for use in the study were identified from the Geospatial Attributes of Gages for Evaluating Streamflow (GAGES II) dataset (Falcone, 2011; Falcone et al., 2010). The GAGES II dataset catalogs several hundred climatological, geological, land cover, water use, hydraulic infrastructure, and geospatial characteristics for more than 9,000 USGS gaged basins. Among these characteristics, the dataset identifies basins that represent hydrologic conditions considered least impacted by human disturbance — classified as reference basins. This study selected candidate gages from a specific subset of reference gages in the Hydroclimatic Data Network-2009 (Lins, 2012). HCDN-2009 gages have a minimum of 20 years of daily streamflow data through 2009 relatively free from human disturbance or alteration and are therefore considered suitable for long-term hydroclimatic study. In an effort to specifically examine snowmelt-related streamflow, the candidate HCDN-2009 gages were restricted to basins that received an average of 30 percent or more of total precipitation as snow during the period 1901-2000; snow-percent estimates were 
based on a monthly snow accumulation and melt model described by McCabe and Wolock (2009) and were obtained from the GAGES II dataset.

Streamflow data were assembled on the basis of water years; a water year is defined as the period from October 1 to September 30 and is designated by the year in which it ends. Daily mean streamflow values through water year 2014 (ending September 30, 2014) were obtained from the USGS National Water Information System (U.S. Geological Survey, 2015) for the study stream gages. Data were subject to length and completeness criteria for the purposes of trend testing. Some previous streamflow-timing trend studies have used stream gages with 20 or more missing years of record within their analysis periods. This approach includes many gages where data collection started substantially later than the indicated study period and results in a mixed population of gages with shorter and longer periods of data. To avoid this issue, but allow gages to have minor amounts of missing data, gages in our study were required to have daily streamflow data at least from 1960 to 2014 (55 years) and have complete data for at least 8 out of every 10 years for each decade (e.g. 1960-1969) and 12 out of the last 15 years (2000-2014) (80percent completeness). In cases where gaged basin areas overlapped by more than 30 percent (a measure of basin nestedness), the gage with the shorter record was excluded.

Long-term median winter-spring hydrographs of candidate study basins were examined for evident snowmelt-related streamflow and to determine the appropriate regional winter-spring period(s) to be used for computing snowmelt related streamflow volume and timing. Only one candidate study basin that met the criteria above did not exhibit a clear snowmelt related signal (a sustained late-winter/spring runoff event) in its long-term median hydrograph and therefore was excluded from the study (USGS station number 12167000, Stillaguamish River near Arlington, Washington). Application of the above selection and data-completeness criteria 
resulted in 75 study gages for the 1960-2014 period (Figure 1); 54 gages for 1940-2014, and 15 gages for 1920-2014.

Examination of the long-term winter-spring hydrographs yielded the following winter-spring windows: Eastern gages, January 1 through May 31; Western gages, January 1 through July 31. These windows were chosen to limit the computation of WSCVD to times of the year when snowmelt predominantly occurs in the different regions. Snowmelt-related streamflow at Western gages often persisted into July, while snowmelt was largely complete by May at Eastern gages. June and July were therefore not included in the winter-spring window for Eastern gages because streamflow during those months represent predominantly rainfall-related streamflow. Though the seasonal windows differ between East and West regions, limiting the computation of WSCVD to times of the year when snowmelt predominantly occurs in each region makes comparison of trend results between regions is more meaningful.

The winter-spring center-volume date (WSCVD, Julian date) for each year was calculated as the date when half of the total streamflow volume during the winter-spring period passed by the gaging station. Winter-spring streamflow volumes (WSV, normalized by drainage area and expressed in centimeters) were computed for each gage on the basis of daily mean streamflow data for the winter-spring period of each water year. WSV composes more than half of the annual streamflow volume (AV, normalized by drainage area and expressed in centimeters) at all study gages; for high-elevation gages in the West, the median ratio of WSV to AV exceeds 80 percent indicating the essential contribution of January-July streamflow to the annual water budget for these basins (Figure 2). Study gage characteristics and computed WSCVD, WSV, and AV data are available at https://doi.org/10.5066/F7R78CBX. 


\subsection{Precipitation and Air Temperature}

We used precipitation and air-temperature data from meteorological stations in the U.S. Historical Climatology Network (USHCN) (Menne et al., 2015)—a 1,218-station subset of the NOAA Cooperative Observer Program Network evaluated on the basis of record length and completeness and historical stability. Monthly data (means for air temperature, totals for precipitation) for the USHCN are computed from quality-controlled daily data from the Global Historical Climatology Network (Menne et al., 2012; Durre et al., 2010). The nearest USHCN station to each study streamflow gage was identified; 58 unique USHCN stations paired with the 75 study gages (Figure 1). Distances between streamflow gages and meteorological stations ranged from $4.5 \mathrm{~km}$ to $78.4 \mathrm{~km}$, with a median distance of $34.3 \mathrm{~km} ; 75$ percent of the gages and stations are within $50 \mathrm{~km}$ of each other. Temperature and precipitation recorded at these meteorological stations may differ from those in the nearby study basins, however, they are expected to be useful in testing the interannual correlation of meteorological conditions and winter-spring streamflow timing. Monthly precipitation and air temperature were obtained from the USHCN version 2.5.0.20150522 dataset (National Oceanic and Atmospheric Administration, 2015). Year-to-year seasonal precipitation totals and air temperature means were computed for various monthly combinations from January through July and were used for correlation testing with annual winter-spring streamflow timing and volume.

\subsection{Ocean-atmosphere indices}

Many studies have documented links between large-scale ocean-atmosphere indices and regional air temperatures, precipitation, and streamflow. The multivariate El-Nino/Southern Oscillation index (MEI) is a measure of El-Nino/Southern Oscillation (ENSO) derived from six metrics in the tropical Pacific: sea-level pressure, zonal and meridional components of surface wind, sea 
surface temperature, surface air temperature, and cloudiness of the sky (Wolter and Timlin, 1993). ENSO has an approximately 2-7 year periodicity. Increased regional precipitation (especially in winter months) in the southwest and central U.S. correlate with positive phases of ENSO (Ropelewski and Halpert, 1986; Hanson et al., 2004; Hanson et al., 2006). The Pacific Decadal Oscillation (PDO) is a measure of North Pacific sea-surface temperatures and has an approximately 10-25 year periodicity. PDO is closely related to ENSO (An et al., 2007; Newman et al., 2003) and correlates with wintertime air temperatures, with the positive phase associated with warmer temperatures in northwestern North America (Mantua et al., 1997).

The Atlantic Multi-decadal Oscillation (AMO) is an index of North Atlantic sea-surface temperatures with an approximately 60-80 year periodicity. Positive phases of the AMO are related to predominantly dry weather over most of North America (Enfield et al., 2001; Feng et al., 2011). The North-Atlantic Oscillation (NAO) is an index of the atmospheric pressure gradient across the North Atlantic between measuring stations in the Azores and Iceland with an approximately 3-6 year periodicity. Peings and Magnusdottir (2014) documented that negative NAO values occur more frequently during warm North Atlantic sea surface temperatures (positive AMO) resulting in colder and drier winter-season air masses over the eastern U.S.

Monthly PDO data were obtained from the University of Washington's Joint Institute for the Study of the Atmosphere and Ocean (accessed December 8, 2015, at http://jisao.washington.edu/pdo/PDO.latest). Monthly AMO, NAO, and MEI data were obtained from NOAA’s Earth Systems Laboratory, Physical Sciences Division (NOAA/ESRL/PSD) (accessed December 8, 2015, at http://www.esrl.noaa.gov/psd/data/correlation/amon.us.data, http://www.esrl.noaa.gov/psd/data/correlation/nao.data, and http://www.esrl.noaa.gov/psd/data/correlation/mei.data, respectively). The MEI is computed on 
twelve sliding bi-monthly seasons and are assigned to the last month in the computation window (e.g. the December-January MEI value is assigned to January).

\subsection{Trends}

The magnitudes of trends in winter-spring streamflow timing and volume were computed with the Sen slope (also known as the Kendall-Theil robust line) which is computed as the median of all possible pairwise slopes in each temporal data set (Helsel and Hirsch, 2002). The slope was multiplied by the appropriate number of years of data to obtain monotonic streamflow-timing and volume trends for different time periods.

We computed the significance of trends using methods that consider the possibility of short and long term persistence in the time-series data. This is an important issue that is often ignored in temporal trend studies. The significance of hydroclimatic trends over time are very sensitive to assumptions of whether the underlying data are independent, have short term persistence, or have long term persistence (Cohn and Lins, 2005; Koutsoyiannis and Montanari, 2007; Hamed, 2008;

Khaliq et al., 2009; Kumar et al., 2009). Further discussion and references on this issue are in Hodgkins and Dudley (2011).

We report trend significance with three different null hypotheses of the serial structure of the time-series data: independence, short-term persistence (AR1), and long-term persistence (LTP) (Hamed and Rao, 1998; Hamed, 2008). Trends were considered significant at $\mathrm{p} \leq 0.05$. Monte Carlo tests were run with synthetic data to see if the levels of persistence and missing values seen in the study data were problematic in terms of nominal vs. actual significance levels; nominal and actual levels were nearly identical. 


\subsection{Correlations}

All correlation testing was done using Pearson's product-moment correlation coefficient $r$. Interannual correlations tested year-to-year values of WSCVD against monthly precipitation, air temperature, and ocean-atmosphere indices for the period 1940-2014, to maximize both the number of gages meeting completeness criteria and the period analyzed for temporal variability. All correlations were considered significant at $\mathrm{p} \leq 0.05$. Field significance was calculated by multiplying the minimum local p-value for the region by the number of tests in the region; this method approximates the Walker test (Wilks, 2006).

\section{Results}

\subsection{Trends}

Trends in winter-spring center volume dates (WSCVD) indicate earlier dates at most (80.0 to 90.8 percent) gages for all three time periods tested (Figure 3, Table 1). Trends were significant at a minority of gages; for 1960-2014, 26.7 percent were significant for the independence timeseries assumption, 28.0 percent for the short-term persistence assumption, and 5.3 percent for the long-term persistence assumption. Trends toward later dates occurred only at 1 gage (of 15) for the 1920-2014 period, at none (of 54) for the 1940-2014 period, and 2 (of 75) for the 1960-2014 period; none of the trends toward later dates were significant.

Gages in the East had median earlier WSCVD by 8.2 and 8.6 days for the 1940-2014 and 19602014 periods respectively (1.1 and 1.6 days/decade); high-elevation gages in the West had median earlier dates by 4.0 and 5.2 days for the same periods ( 0.5 and 0.9 days/decade). Low-tomid elevation gages in the West measured the largest variations in WSCVD trends between the 
longer and shorter periods with earlier dates by 6.8 and 3.4 days respectively ( 0.9 and 0.6 days/decade) (Figure 4).

Trends in winter-spring streamflow volume (WSV) indicate increases at 44.4 to 60.0 percent of gages across the three time periods (Table 1) with increases predominant in the Northeast and mixed trends in the West with a majority of decreases (not shown); few trends were significant. Decreases occurred at 26.7 to 50.0 percent of gages; mostly in the western U.S. and Michigan. Trend results for WSCVD and WSV by gage and time period are available at https://doi.org/10.5066/F7R78CBX.

\subsection{Interannual Correlations of Snowmelt-Related Streamflow Timing with Air}

Temperature and Precipitation, 1940-2014

Winter-spring center-volume dates (WSCVD) and air temperatures correlated significantly for certain months at all gages in all regions (Table 2); for all months, earlier WSCVD correlated with higher temperatures. In general, WSCVD correlated most strongly (for single-month values) with March air temperatures at basins in the East, April temperatures at high elevation basins in the West, and March temperatures at low-to-mid elevation basins in the West (Table 2). WSCVD was significantly correlated with mean February-May air temperature at 100 percent of the study gages across the U.S. (field significant, $\mathrm{p}<0.0001$ ). WSCVD correlated most strongly with mean March-April air temperatures in the East $(r=-0.62)$, February-May at low-to-mid elevation basins in the West $(r=-0.53)$, and April-June in high elevation basins in the West $(r=$ $-0.73)$.

High elevation basins in the West had the greatest number of basins with significant correlations between WSCVD and precipitation for most months (Table 3), with later dates associated with 
greater amounts of seasonal precipitation; total January-June precipitation had significant correlations at 96.2 percent of the high elevation basins in the West (mean $r=+0.51$ ). Seasonal precipitation contributes directly to WSV; therefore WSCVD and WSV also were significantly correlated at most high elevation basins in the West (Figure 5). Earlier WSCVD correlated significantly with greater January precipitation at half the basins in the East. There were few significant correlations of WSCVD with precipitation at low-to-mid elevation basins in the West.

\subsection{Interannual Correlations of Snowmelt-Related Streamflow Timing with Ocean-}

\section{Atmosphere Indices}

WSCVD had significant correlations with both PDO and MEI at a high percentage of low-to-mid elevation basins in the West (Table 4). Earlier WSCVD in the Northwest and some basins in northern New England, and later dates at a few basins in the Southwest had significant correlations with positive-phase April-May PDO and MEI (Figure 6).

Earlier WSCVD was significantly correlated with April-May positive-phase NAO at many high elevation basins in the southwestern and interior U.S. (Figure 7a). Earlier WSCVD was significantly correlated with positive-phase May AMO among the northernmost basins in the East (Figure 7b).

\section{Discussion}

\subsection{Time series structure of the data}

This study found differences in the percentage of stations with significant trends in snowmeltrelated streamflow timing, depending on the assumed time-series structure of the data (Table 1). The numbers of significant trends based on assumptions of both independence (that the year-toyear WSCVD are independent) and short-term persistence (lag one year autocorrelation) were 
approximately equal, and there were fewer significant trends based on the assumption of longterm persistence for all time periods considered. The presence of long-term persistence indicates that a process is compatible with variability at a range of timescales, which may reflect long-term variability due to factors such as solar forcing, volcanic activity, and others (Koutsoyiannis and Montanari, 2007). The occurrence of fewer significant trends in the context of long-term persistence has been shown previously for climate-related trends (e.g. Cohn and Lins, 2005; Hamed, 2008; Khaliq et al., 2009). For the current study, long-term persistence could be present, potentially related to multi-decadal ocean-atmosphere patterns such as the Pacific Decadal Oscillation.

Among the various assumptions of the time-series structure of the data, we considered what might be the most reasonable assumption to use for trends in snowmelt-related streamflow timing. The presence of long-term persistence in hydroclimatic data series is difficult to prove without very long records (generally greater than 100 years) (Vogel et al., 1998; Khaliq et al., 2009), however we can look for proof of short term persistence using lag one autocorrelation tests. The number of gages across all regions with significant $(\mathrm{p} \leq 0.05)$ short term persistence was very few; 1 of 15 gages for 1920-2014, 2 of 54 for 1940-2014, and 0 of 75 for 1960-2014; with average correlation coefficients of $-0.05,0.03$, and 0.03 respectively. Given the general lack of evidence of short-term persistence in snowmelt-related streamflow timing, we fail to prove the presence of short term persistence in the data and conclude data independence is likely an appropriate assumption for these data series.

\subsection{Streamflow timing as an indicator of snowmelt timing}

Whitfield (2013) criticized the use of streamflow timing as an indicator of the timing of snowmelt (for example the date in which 50 percent of the annual flow has occurred) because it 
is neither "specific nor robust". Whitfield (2013) points out that other influences, such as base flows and winter rain can affect the indicator, making it not specific (less sensitive to snowmelt timing). He also shows that the choice of calendar year vs. water year can affect the indicator, making it not robust. While these points are valid, we believe that some of these issues can be minimized and that the timing of snowmelt-related streamflow is an important metric, whether or not it represents only snowmelt.

The use of seasonal streamflow timing metrics (e.g. Hodgkins and Dudley, 2006), rather than the annual streamflow timing metrics discussed by Whitfield (2013), reduces the influence of nonsnowmelt related processes. For example, the use of a winter-spring metric versus a metric based on annual streamflow removes the influence of any fall high flows on streamflow timing. Another way to minimize non-snowmelt related processes on streamflow timing is to analyze only basins where snowmelt is a major part of streamflow, for example basins where at least 50 percent of the annual streamflow occurs during April through July (e.g. Regonda et al., 2005; McCabe and Clark, 2005).

It is important to analyze the relation between snowmelt-related streamflow timing and likely important contributing factors, including air temperature and precipitation. As discussed above, streamflow timing may be influenced by both spring air temperatures and winter precipitation. Because of its importance for water supply and other issues, however, snowmelt-related streamflow timing is an important indicator of climatic changes, regardless of whether it is affected by multiple factors. More winter rain, rather than snow, will lead to earlier streamflow timing and less snowpack to melt later during the primary snowmelt season. More winter rain and earlier snowmelt both are related to increased air temperatures. 
Whitfield (2013) tested the computation of annual center-of-volume date over a range of base flow to snowmelt volume ratios and showed that base flow could substantially affect streamflow timing when base flow volume was larger than snowmelt volume. We have attempted to minimize this potential complicating factor for our streamflow timing metric (winter-spring center volume date) by limiting candidate gages to basins that received an average of 30 percent or more of total precipitation as snow and limiting our metric to months when snowmelt predominantly occurs. We believe that snowmelt-related streamflow during winter-spring months dominates base flow contributions to streamflow.

\subsection{Regional similarities and differences}

Widespread trends toward earlier WSCVD were observed across the conterminous U.S. at most basins for all time periods tested; this is consistent with other studies that reported declining snowpack and earlier snowmelt-related streamflow timing in the West (Regonda et al., 2005; Mote et al., 2005; Stewart et al., 2005; Dettinger and Cayan, 1995) and the East (Hodgkins and Dudley, 2006; Burns et al., 2007). In the current study, most of the gages in the East showed significant trends (Figure 3), and while there were fewer gages with significant trends in the West, most trends were toward earlier WSCVD, some showed little change, and two indicated non-significant later dates (Figure 3).

\subsubsection{Eastern basins}

Interannual March and April mean air temperatures significantly correlated with WSCVD at all gaging stations in the East (Table 2). Interannual variability in March-April mean air temperature explained about 39 percent $\left(r^{2}\right)$ of the variability in WSCVD at basins in the East, while precipitation had little correlation with WSCVD (Table 3). Hodgkins et al. (2003) also 
observed air temperatures had much higher correlations with earlier streamflow timing than did precipitation for basins in New England.

Given the interannual correlations between WSCVD and air temperature, the significant trends in WSCVD (Figure 3) are likely related to temperature increases over time. During 1940-2014, mean WSCVD among all basins in the East that qualified for trend testing occurred 7.7 days earlier based on Sen slope ( $\mathrm{p}=0.03$ based on Mann-Kendall test with independence assumption) (Figure 8a). Regional mean (for stations near the basins) February-May air temperatures increased by $0.93^{\circ} \mathrm{C}(\mathrm{p}=0.05)$ (Figure $\left.8 \mathrm{~b}\right)$, and seasonal (January-May) total precipitation increased by $2.1 \mathrm{~cm}(\mathrm{p}=0.44)$ (Figure $8 \mathrm{c})$ for this period. Regional mean WSCVD correlated significantly with regional mean February-May air temperature $(\mathrm{r}=-0.70, \mathrm{p}<0.0001)$ and was uncorrelated with seasonal (January-May) total precipitation $(r=-0.04, p=0.73)$. The correlation of WSCVD with temperature was unchanged when the variance related to precipitation was removed using semi-partial correlation.

Earlier WSCVD during 1960-2014 in the East also were correlated with positive phase May AMO $\left(r^{2}=0.11\right.$, for gages with significant correlations) (Table 4, Figure 7b). Arguez et al. (2009) found positive correlation between air temperature anomalies over eastern North America and the AMO.

\subsubsection{Western basins}

Stewart et al. (2005) found that both temperature and precipitation affect streamflow timing in the West, with temperature being the dominant variable. We found interannual winter-spring streamflow timing for basins throughout the West was clearly related with seasonal air

temperatures (Table 2). WSCVD also was correlated with precipitation-predominantly in high elevation basins (mean basin elevation higher than 1,600 m, Table 3). 


\subsubsection{Western basins, low-to mid-elevation}

Most of the low-to mid-elevation western basins in this study were in the Northwest (Figure 1). Interannual variability in mean February-May air temperature explained about 29 percent of the variability in year-to-year WSCVD at these basins. During 1940-2014, mean WSCVD among low-to-mid elevation western basins that qualified for trend testing occurred 6.8 days earlier based on Sen slope ( $p=0.11$ based on Mann-Kendall test with independence assumption) (Figure 8a), February-May air temperatures increased by $0.65^{\circ} \mathrm{C}(\mathrm{p}=0.05)$ (Figure $\left.8 \mathrm{~b}\right)$, and seasonal (January-July) total precipitation increased by $9.9 \mathrm{~cm}(\mathrm{p}=0.007)$ (Figure 8c). Regional mean WSCVD correlated significantly with regional mean February-May air temperature $(\mathrm{r}=$ $0.74, \mathrm{p}<0.0001)$ and was uncorrelated with seasonal (January-July) total precipitation $(\mathrm{r}=-$ $0.07, \mathrm{p}=0.57)$. The correlation of WSCVD with temperature was unchanged when the variance related to precipitation, was removed.

Earlier WSCVD during 1950-2014 (period of data available for ocean-atmosphere indices) for low-to-mid elevation basins in the West were related to positive phase May PDO $\left(r^{2}=0.27\right)$ and MEI $\left(r^{2}=0.18\right)$, for gages with significant correlations (Table 4, Figure 6); both correlations were field significant $(\mathrm{p}<0.0001)$. These correlations are consistent with observations of warmer and drier conditions during positive phase ENSO (Kuss and Gurdak, 2014; McCabe et al., 2012). WSCVD was field-significantly correlated with PDO and MEI during January through July with May having the highest mean correlation values (Table 4).

Trends toward earlier streamflow timing in the Northwest in this study were not statistically significant, differing from previous studies that observed many large and (or) significant trends in this region (McCabe and Clark, 2005; Regonda et al. 2005; Stewart et al. 2005). Much of this difference is likely related to the sensitivity of trend tests to the time period being tested, 
particularly the beginning and end times (Figure 8a). The periods of time examined by McCabe and Clark (2005), Regonda et al. (2005), and Stewart et al. (2005) were 1950-2003, 1950-1999, and 1948-2002, respectively. Our time periods for trend testing began in 1940 and 1960 which both had warmer winter-spring air temperatures than the period near 1950, and regional winterspring air temperatures have been generally declining slightly since the 1990's (Figure 8b).

While trends in WSCVD for our study still indicated earlier dates over the 1940- and 1960-2014 periods, the recent years of winter-spring temperatures and the relatively warm periods anchoring the start of the 1940 and 1960 time series likely contributed to trends not being statistically significant (Figure 8a and 8b). Another factor to consider is the differences in the streamflow timing metrics used among the studies. Our study used a seasonal (January-July) center-volume date while McCabe and Clark (2005) and Regonda et al. (2005) used an annual center-volume date and Stewart et al. (2005) used an annual center-of-mass date.

\subsubsection{Western basins, high-elevation}

The high-elevation western basins in this study were generally in the interior West and Southwest (Figure 1). April-June mean air temperature explained 53 percent of the interannual variability in streamflow timing at these basins while March-June precipitation explained 27 percent. Interannual winter-spring streamflow timing also was significantly correlated with winter-spring volume at nearly all of these gages (Figure 5) indicating later dates correlated with greater volume. Winter-spring volume measured in high elevation basins is likely a good proxy for snowpack because of the cold winter temperature regime at these sites; therefore later WSCVD corresponds with deeper snowpack.

During 1940-2014, mean regional WSCVD among high-elevation western basins that qualified for trend testing occurred 5.3 days earlier based on Sen slope $(p=0.11$ based on Mann-Kendall 
test with independence assumption) (Figure 8a), February-May air temperatures increased by $1.2^{\circ} \mathrm{C}(\mathrm{p}=0.0006)$ (Figure $\left.8 \mathrm{~b}\right)$, and seasonal (January-July) total precipitation decreased by 3.0 $\mathrm{cm}(\mathrm{p}=0.18)($ Figure $8 \mathrm{c})$. Regional mean WSCVD correlated significantly with regional mean February-May air temperature $(\mathrm{r}=-0.63, \mathrm{p}<0.0001)$ and significantly correlated with seasonal (January-July) total precipitation $(\mathrm{r}=0.63, \mathrm{p}<0.0001)$. The correlations of WSCVD with temperature and precipitation both increased $(r=-0.70, r=0.69$, respectively) when the variance related to precipitation, and temperature was respectively removed. Earlier WSCVD correlated with warmer and drier conditions; later WSCVD with colder and wetter conditions. The 25 years with the earliest WSCVDs during 1940-2014 had, on average, February-May mean air temperatures $1.4^{\circ} \mathrm{C}$ warmer and seasonal total precipitation $7.4 \mathrm{~cm}$ less than years with the 25 latest WSCVDs. The difference in the average WSCVD between the latest years and the earliest years was 17 days.

Earlier streamflow timing at high elevation basins in the western U.S. was associated with positive NAO $\left(r^{2}=0.13\right)$ for gages with significant correlations, (Figure 7a). Myoung et al., (2015) have linked air temperatures in the southwestern U.S. with NAO, observing higher March-June air temperatures associated with positive phase NAO. The NAO effect on air temperatures in the southwestern U.S. is attributed the presence of upper-tropospheric anticyclones over the region associated with the positive-phase NAO (Myoung et al. 2015).

Streamflow timing was not significantly correlated with MEI and PDO at most high-elevation gages in the West (Figure 6). As discussed previously, the observed correlations of MEI and PDO with precipitation and air temperatures in the western U.S. exhibit a dipole pattern (Kuss and Gurdak, 2014). Many of the high elevation basins are not near the locations of maximum 
climatic impacts related to the phenomena measured by MEI and PDO and are likely not strongly affected in one direction, unlike the low-to-mid elevation basins in the Northwest.

\section{Conclusions}

We present an analysis of historical trends in snowmelt-related streamflow timing for the conterminous U.S. through 2014. Winter-spring streamflow timing and volume were computed on the basis of daily mean streamflow data from 75 basins with minimal hydrologic disturbance where at least 30 percent of annual precipitation is received as snow. Streamflow data were restricted to regional winter-spring periods to focus on snowmelt-related streamflow and likely important contributing factors to snowpack accumulation and melt, including air temperature and precipitation.

Widespread trends toward earlier winter-spring center volume dates (WSCVD) related to warmer air temperatures were observed across the conterminous U.S. at most basins for the 1920-, 1940-, and 1960-2014 time periods tested. Presentation of results focused on the 1940-, and 1960-2014 time periods because data available for analysis for 1920-2014 was very limited. Gages in the East had median earlier WSCVD by 8.2 and 8.6 days for the 1940-2014 and 19602014 periods respectively; low-to-mid elevation $(<1,600 \mathrm{~m})$ basins in the West had median earlier WSCVD by 6.8 (1940-2014) and 3.4 (1960-2014) days; and high-elevation ( $\geq 1,600 \mathrm{~m})$ basins in the West had median earlier WSCVD by 4.0 (1940-2014) and 5.2 (1960-2014) days. Trends in WSCVD at the 30 study gages in the eastern U.S. were generally homogenous and significant, and interannual WSCVD variability was found to be mostly related to seasonal air temperatures. Fewer WSCVD trends in the West were significant though results indicated regionally coherent trends toward earlier dates. WSCVD at the 19 low-to-mid elevation study 
basins in the West, mostly located in the Northwest, was predominantly related to air temperature. Differences in the overall trend significance between this study and previous studies for snowmelt-related streamflow timing in the Northwest is likely related to the sensitivity of trend tests to the time period being tested and differences in the streamflow timing metrics used among the studies. WSCVD at the 26 high-elevation study basins in the West was explained by both seasonal air temperature and precipitation; timing also was related to winter-spring streamflow volume, an indicator of winter snowpack for these basins. Greater winter-spring volume correlated with later WSCVD.

The significant changes in WSCVD in the East during 1940-2014 were likely driven primarily by the $0.93^{\circ} \mathrm{C}$ increase in February-May air temperatures during this period; a small amount of interannual variability in timing was explained by the positive correlation with May Atlantic Multidecadal Oscillation. Pacific Decadal Oscillation and El Nino Southern Oscillation (measured by MEI) correlated with WSCVD among low-to-mid elevation basins in the West (mostly located in the Northwest).

WSCVD was significantly correlated with mean February-May air temperature at 100 percent of the study gages (field significant, $\mathrm{p}<0.0001$ ). Future air temperature increases are expected (Intergovernmental Panel on Climate Change, 2014), as is earlier snowmelt-related streamflow timing due to earlier snowmelt and the increased likelihood of rain instead of snow (Arora and Boer, 2001). It is important to note however, that precipitation quantity also plays an important role in snowmelt-related streamflow timing in high elevation basins in the West; timing in these basins is a product of the interaction between both air temperature and precipitation yielding earlier WSCVD under warmer and drier conditions. Where snowmelt in these basins contributes significantly to water supply, changes toward earlier snowmelt-related streamflow timing may 
indicate lower summer water availability and lead to water availability issues for municipal water supply, agriculture, power generation, and ecosystems. The WSCVD indicator of snowmelt-related streamflow timing is useful for understanding the effects of historical and projected climatic changes on important water-resources related issues.

\section{Acknowledgements}

We thank David Wolock, USGS, and two anonymous reviewers for their helpful reviews and suggestions that improved the quality of this manuscript. This work was supported by the U.S.

Environmental Protection Agency's Office of Atmospheric Programs, Climate Change Division.

\section{References}

Aguado, E., Cayan, D, Riddle, L, and Roos, M., 1992, Climatic fluctuations and the timing of West Coast streamflow, Journal of Climate 5: 1468-1483.

An, S.I., Kug, J.S., Timmermann, A., Kang, I.S., and Timm, O., 2007, The influence of ENSO on the generation of decadal variability in the North Pacific: Journal of Climate, vol. 20, no. 4, p. 667-680.

Arguez, A., O’Brien, J.J., and Smith, S.R., 2009, Air temperature impacts over eastern North America and Europe associated with low-frequency North Atlantic SST variability: International Journal of Climatology, vol. 29, doi: 10.1002/joc.1700.

Arora, V.K., and Boer, G.J., 2001, Effects of simulated climate change on the hydrology of major river basins, Journal of Geophysical Research 106, 3335-3348.

Barnett, T.P., Adam, J.C., and Lettenmaier, D.P., 2005, Potential impacts of a warming climate on water availability in snow-dominated regions, Nature 438: 303-309. 
Burns, D.A., Klaus, J., and McHale, M.R., 2007, Recent climate trends and implications for water resources in the Catskill Mountain region, New York, USA. J. Hydrol. 336(12):155-170.

Cayan, D.R., Kammerdiener, S.A., Dettinger, M.D., Caprio, J.M., and Peterson, D.H., 2001, Changes in the onset of spring in the western United States, Bulletin of the American Meteorological Society 82: 399-415.

Clark, G.M., 2010, Changes in patterns of streamflow from unregulated watersheds in Idaho, western Wyoming, and northern Nevada, Journal of the American Water Resources Association 46: 486-497.

Clow, D.W., 2010, Changes in the timing of snowmelt and streamflow in Colorado: A response to recent warming, Journal of Climate 23: 2293-2306.

Cohn, T.A., and H.F. Lins. 2005. Nature's style: Naturally trendy. Geophys. Res. Lett. 32:L23402.

Dettinger, M.D., 2005, Changes in Streamflow Timing in the Western United States in Recent Decades - from the National Streamflow Information Program: U.S. Geological Survey Fact Sheet 2005-3018, 4 p.

Dettinger, M.D., and Cayan, D.R., 1995, Large-scale atmospheric forcing of recent trends toward early snowmelt runoff in California, Journal of Climate 8: 606-623.

Durre I., M. J. B.E. Gleason, T. G. Houston, and R. S. Vose, 2010, Comprehensive automated quality assurance of daily surface observations: Journal of Applied Meteorology and Climatology, vol. 49, pp. 1615-1633. 
Enfield D.B., Mestas-Nunez, A.M., and Trimble, P., 2001, The Atlantic multidecadal oscillation and its relation to rainfall and river flows in the continental U.S.: Geophysical Research Letters, vol. 28, no. 10, pp. 2077-2080.

Falcone, J.A., 2011, GAGES-II-Geospatial attributes of gages for evaluating streamflow: U.S. Geological Survey metadata, accessed August 25, 2015, at http://water.usgs.gov/GIS/metadata/usgswrd/XML/gagesII_Sept2011.xml

Falcone, J.A., Carlisle, D.M., Wolock, D.M., and Meador, M.R., 2010, GAGES—A stream gage database for evaluating natural and altered flow conditions in the conterminous United States: Ecology, v. 91, no. 2, p. 621, accessed August 25, 2015, at http://esapubs.org/Archive/ecol/E091/045/metadata.htm.

Feng, S., and Hu, Q., 2007, Changes in winter snowfall/precipitation ratio in the contiguous United States: Journal of Geophysical Research, vol. 12, D15109, doi:10.1029/2007JD008397.

Feng, S., Hu, Q., Oglesby, R.J., 2011, Influence of Atlantic sea surface temperatures on persistent drought in North America: Climate Dynamics, 37:569-586, doi 10.1007/s00382-010-0835-x.

Fritze, H., Stewart, I.T., and Pemesma, E., 2011, Shifts in western North American snowmelt runoff regimes for the recent warm decades: Journal of Hydrometeorology 12, 989-1006.

Hall, D.K., Crawford, C.J., DiGirolamo, N.E., Riggs, G.A., and Foster, J.L., 2015, Detection of earlier snowmelt in the Wind River Range, Wyoming, using Landsat imagery, 19722013. Remote Sensing of Environment, vol. 162, pp. 45-54. 
Hamed, K.H., 2008, Trend detection in hydrologic data: The Mann-Kendall trend test under the scaling hypothesis, J. Hydrol. 349: 350-363.

Hamed, K.H., and Rao, R., 1998, A modified Mann-Kendall trend test for autocorrelated data, J. Hydrol. 204: 182-196.

Hamlet, A.F., Mote, P.W., Clark, M.P., and Lettenmaier, D.P., 2005, Effects of temperature and precipitation variability on snowpack trends in the western United States: Journal of Climate, vol. 18, pp. 4545-4561.

Hayhoe, K., Wake, C.P., Huntington, T.G., Luo, L., Schwartz, M.D., Sheffield, J., Wood, E., Anderson, B., Bradbury, J., DeGaetano, A. and Troy, T.J., 2007, Past and future changes in climate and hydrological indicators in the US Northeast, Climate Dynamics 28, 381407.

Hanson, R.T., Dettinger, M.D., Newhouse, M.W., 2006. Relations between climatic variability and hydrologic time series from four alluvial basins across the southwestern United States. Hydrogeol. J. 14 (7), 1122-1146. http://dx.doi.org/10.1007/s10040-006-0067-7.

Hanson, R.T., Newhouse, M.W., Dettinger, M.D., 2004. A methodology to assess relations between climatic variability and variations in hydrologic time series in the southwestern United States. J. Hydrol. 287 (1), 252-269. http://dx.doi.org/10.1016/j.jhydrol.2003.10.006.

Helsel, D.R., and Hirsch, R.M., 2002, Statistical methods in water resources: U.S. Geological Survey Techniques of Water-Resources Investigations, book 4, chap. A3, 522 p. [Also available at http://pubs.usgs.gov/twri/twri4a3/.] 
Hodgkins, G.A., and Dudley, R.W., 2006, Changes in the timing of winter-spring streamflows in eastern North America, 1913-2002. Geophys. Res. Lett. 33:L06402.

Hodgkins, G.A., and Dudley, R.W., 2011, Historical summer base flow and stormflow trends for New England rivers, Water Resources Research 47, W07528, doi:10.1029/2010WR009109.

Hodgkins, G.A., Dudley, R.W., and Huntington, T.G., 2003, Changes in the timing of high river flows in New England over the 20th Century, Journal of Hydrology 278: 244-252.

Huntington, T.G., Hodgkins, G.A., Keim, B.D., and Dudley, R.W., 2004, Changes in the proportion of precipitation occurring as snow in New England (1949-2000): Journal of Climate, v. 17, no. 13, p. 2626-2636, http://dx.doi.org/10.1175/15200442(2004)017<2626:CITPOP>2.0.CO;2.

Intergovernmental Panel on Climate Change, 2014: Climate Change 2014: Synthesis Report. Contribution of Working Groups I, II and III to the Fifth Assessment Report of the Intergovernmental Panel on Climate Change [Core Writing Team, R.K. Pachauri and L.A. Meyer (eds.)]. IPCC, Geneva, Switzerland, 151 pp.

Karl, T. R., Melillo, J.T., and Peterson, T.C., Eds., 2009, Global Climate Change Impacts in the United States: Cambridge University Press, 189 pp.

Khaliq, M.N., T.B.M.J. Ouarda, and P. Gachon, 2009, Identification of temporal trends in annual and seasonal low flows occurring in Canadian rivers: The effect of short- and long-term persistence, J. Hydrol. 369: 183-197. 
Knowles, N., Dettinger, M.D., and Cayan, D.R., 2006, Trends in snowfall versus rainfall in the western United States: Journal of Climate, vol. 19, p. 4545-4559.

Koutsoyiannis, D., and A. Montanari. 2007. Statistical analysis of hydroclimatic time series: Uncertainty and insights. Water Resour. Res. 43(5):W05429.

Kumar, S., V. Merwade, J. Kam, and K. Thurner, 2009, Streamflow trends in Indiana: Effects of long term persistence, precipitation and subsurface drains, J. Hydrol. 374: 171-183.

Kunkel, K.E., M. Palecki, L. Ensor, K.G. Hubbard, D. Robinson, K. Redmond, and D. Easterling, 2009, Trends in twentieth-century U.S. snowfall using a quality-controlled dataset: J. Atmos. Ocean. Tech. vol. 26, pp. 33-44.

Kuss, A.J.M., and Gurdak, J.J., 2014, Groundwater level response in U.S. principal aquifers to ENSO, NAO, PDO, and AMO: Journal of Hydrology, 519, 1939-1952. http://dx.doi.org/10.1016/j.jhydrol.2014.09.069

Lins, H.F. 2012. USGS Hydro-Climatic Data Network 2009 (HCDN-2009). U.S. Geological Survey Fact Sheet 2012-3047

Mantua, N.J., Hare, S.R., Zhang, Y., Wallace, J.M., and Francis, R.C., 1997, A Pacific interdecadal climate oscillation with impacts on salmon production: Bulletin of the American Meteorological Society, vol. 78, no. 6, p 1069-1079.

McCabe, G.J., Ault, T.R., Cook, B.I., Betancourt, J.L., and Schwartz, M.D., 2012, Influences of the El Nino Southern Oscillation and the Pacific Decadal Oscillation on the timing of the North American spring: International Journal of Climatology, vol. 32, doi: 10.1002/joc.3400. 
McCabe, G.J., and Clark, M.P., 2005, Trends and variability in snowmelt runoff in the western United States, Journal of Hydrometeorology 6: 476-482.

McCabe, G.J., and Wolock, D.M., 2009, Recent declines in western U.S. snowpack in the context of 20th century climate variability, Earth Interact., 13, $12 \mathrm{p}$.

McCormick, S. D., L. P. Hansen, T. P. Quinn, and R. L. Saunders, 1998, Movement, migration, and smolting of Atlantic salmon (Salmo salar), Can. J. Fish. Aquat. Sci., 55, suppl. 1, 7792.

McRoberts, D.B., and Nielsen-Gammon, J.W., 2011, A new homogenized climate division precipitation dataset for analysis of climate variability and climate change: Journal of Applied Meteorology and Climatology, vol. 50, pp. 1187-1199, doi:10.1175/2010JAMC2626.1

Menne, M. J., Williams, C.N., Jr., and Palecki, M.A., 2010, On the reliability of the U.S. surface temperature record: Journal of Geophysical Research, vol. 115, doi:10.1029/2009JD013094.

Menne, M.J., Williams, C.N., and Vose, R.S., 2015, United States Historical Climatology Network (USHCN) Version 2.5 Serial Monthly Dataset: Carbon Dioxide Information Analysis Center, Oak Ridge National Laboratory, Oak Ridge, Tennessee

Menne, M.J., Durre, I., Vose, R.S., Gleason, B.E., and Houston, T.G., 2012, An overview of the Global Historical Climatology Network-Daily Database: Journal of Atmospheric and Oceanic Technology, vol. 29, pp. 897-910. 
Mote, P.W., Hamlet, A.F., Clark, M.P., and Lettenmaier, D.P., 2005, Declining mountain snowpack in western North America: Bulletin of the American Meteorological Society, $86,39-49$.

Myoung, B., Kim, S.H., Kim, J., and Kafatos, MC., 2015, On the relationship between the North Atlantic Oscillation and early warm season temperatures in the southwestern United States: Journal of Climate, doi: 10.1175/JCLI-D-14-00521.1

National Oceanic and Atmospheric Administration, 2015, National Centers for Environmental Information, U.S. Historical Climatology Network Version 2.5 Serial Monthly Dataset, accessed July 13, 2015, at ftp://ftp.ncdc.noaa.gov/pub/data/ushcn/v2.5

Newman, M., Compo, G.P., and Alexander, M.A., 2003, ENSO-forced variability of the Pacific Decadal Oscillation: Journal of Climate, vol. 16, no. 23, p. 3853-3857.

Pederson, G.T., Gray, S.T., Ault, T., Marsh, W., Fagre, D.B., Bunn, A.G., Woodhouse, C.A., and Graumlich, L.J., 2011, Climatic controls on the snowmelt hydrology of the northern Rocky Mountains, Journal of Climate 24: 1666-1687.

Peterson, T. C., R. R. Heim, R. Hirsch, D. P. Kaiser, H. Brooks, N. S. Diffenbaugh, R. M. Dole, J. P. Giovannettone, K. Guirguis, T. R. Karl, R. W. Katz, K. Kunkel, D. Lettenmaier, G. J. McCabe, C. J. Paciorek, K. R. Ryberg, S. Schubert, V. B. S. Silva, B. C. Stewart, A. V. Vecchia, G. Villarini, R. S. Vose, J. Walsh, M. Wehner, D. Wolock, K. Wolter, C. A. Woodhouse, and D. Wuebbles, 2013, Monitoring and understanding changes in heat waves, cold waves, floods and droughts in the United States-State of knowledge: Bulletin of the American Meteorological Society, pp. 821-834, doi:10.1175/ BAMS-D12-00066.1. 
Peings, Y., and Magnusdottir, G., 2014, Forcings of the wintertime atmospheric circulation by the multidecadal fluctuations of the North Atlantic Ocean: Environmental Research Letters, vol. 9, no. 3, http://dx.doi.org/10.1088/1748-9326/9/3/034018.

Regonda, S.K., Rajagopalan, B., Clark, M., and Pitlick, J., 2005, Seasonal cycle shifts in hydroclimatology over the western United States, Journal of Climate 18: 372-384.

Ropelewski, C.F., Halpert, M.S., 1986, North American Precipitation and Temperature Patterns Associated with the El Niño/Southern Oscillation (ENSO): Monthly Weather Review, vol. 114, pp. 2352-2362.

Roy, S. B., Chen, L., Girvetz, E.H., Maurer, E.P., Mills, W.B., and Grieb, T.M., 2012, Projecting water withdrawal and supply for future decades in the U.S. under climate change scenarios: Environmental Science \& Technology, vol. 46, pp. 2545-2556, doi:10.1021/es2030774.

Ryberg, K.R., Akyüz, F.A., Wiche, G.J., and Lin, W., 2015, Changes in seasonality and timing of peak streamflow in snow and semi-arid climates of the north-central United States, 1910-2012, Hydrological Processes, DOI: 10.1002/hyp.10693.

Stewart, I.T., Cayan, D.R., and Dettinger, M.D., 2004, Changes in snowmelt runoff timing in Western North America under a 'business as usual' climate change scenario, Climatic Change 62: 217-232.

Stewart, I.T., Cayan, D.R., and Dettinger, M.D., 2005, Changes toward earlier streamflow timing across western North America, Journal of Climate 18: 1136-1155. 
U.S. Environmental Protection Agency, 2014, Climate change indicators in the United States, 2014-Third edition: EPA 430-R-14-004, http://www.epa.gov/climatechange/indicators

U.S. Geological Survey, 2015, USGS water data for the nation: U.S. Geological Survey National Water Information System Web interface, accessed September 21, 2015, at http://waterdata.usgs.gov/nwis/

Vose, R.S., Applequist, S., Menne, M.J., Williams, C.N. Jr., and Thorne, P.W., 2012, An intercomparison of temperature trends in the US Historical Climatology Network and recent atmospheric reanalyses: Geophysical Research Letters, vol. 39, doi:10.1029/2012GL051387

Westerling, A.L., Hidalgo, H.G., Cayan, D.R., and Swetnam, T.W., 2006, Warming and earlier spring increase western U.S. Forest Wildfire Activity: Science 313, 940-943.

Westerling, A.L., 2016, Increasing western US forest wildfire activity: sensitivity to changes in the timing of spring: Philosophical Transactions of the Royal Society B, 371: 20150178, http://dx.doi.org/10.1098/rstb.2015.0178

Whitfield, P.H., 2013, Is 'Centre of Volume' a robust indicator of changes in snowmelt timing?: Hydrological Processes, vol. 27, p. 2691-2698, DOI: 10.1002/hyp.9817

Wilks, D.S., 2006, On "field significance" and the false discovery rate: Journal of Applied Meteorology and Climatology, 45, 1181-1189.

Williams, C.N., Menne, M.J., and Thorne, P.W., 2012, Benchmarking the performance of pairwise homogenization of surface temperatures in the United States: Journal of Geophysical Research, 117, 16, doi:10.1029/2011JD016761 
Wolter, K., and M.S. Timlin, 1993, Monitoring ENSO in COADS with a seasonally adjusted principal component index: Proc. of the 17th Climate Diagnostics Workshop, Norman, OK, NOAA/NMC/CAC, NSSL, Oklahoma Clim. Survey, CIMMS and the School of Meteor., Univ. of Oklahoma, pp. 52-57. 


\begin{tabular}{|c|c|c|c|c|c|c|c|c|c|}
\hline \multirow[t]{2}{*}{ WSCVD } & \multicolumn{3}{|c|}{$1920-2014(n=15)$} & \multicolumn{3}{|c|}{$1940-2014(n=54)$} & \multicolumn{3}{|c|}{$1960-2014(n=75)$} \\
\hline & INDE & AR1 & LTP & INDE & AR1 & LTP & INDE & AR1 & LTP \\
\hline Significant earlier & 13.3 & 13.3 & 13.3 & 25.9 & 24.1 & 9.3 & 26.7 & 28.0 & 5.3 \\
\hline Earlier & 66.7 & 66.7 & 66.7 & 64.8 & 66.7 & 81.5 & 62.7 & 61.3 & 84.0 \\
\hline No change & 13.3 & 13.3 & 13.3 & 9.3 & 9.3 & 9.3 & 8.0 & 8.0 & 8.0 \\
\hline Later & 6.7 & 6.7 & 6.7 & 0.0 & 0.0 & 0.0 & 2.7 & 2.7 & 2.7 \\
\hline Significant later & 0.0 & 0.0 & 0.0 & 0.0 & 0.0 & 0.0 & 0.0 & 0.0 & 0.0 \\
\hline \multirow[t]{2}{*}{ WSV } & \multicolumn{3}{|c|}{$1920-2014(n=15)$} & \multicolumn{3}{|c|}{$1940-2014(n=54)$} & \multicolumn{3}{|c|}{$1960-2014(n=75)$} \\
\hline & INDE & AR1 & LTP & INDE & AR1 & LTP & INDE & AR1 & LTP \\
\hline Significant decrease & 0.0 & 0.0 & 0.0 & 0.0 & 0.0 & 0.0 & 2.7 & 1.3 & 0.0 \\
\hline Decrease & 26.7 & 26.7 & 26.7 & 50.0 & 50.0 & 50.0 & 41.3 & 42.7 & 44.0 \\
\hline No change & 13.3 & 13.3 & 13.3 & 5.6 & 5.6 & 5.6 & 0.0 & 0.0 & 0.0 \\
\hline Increase & 60.0 & 60.0 & 60.0 & 44.4 & 44.4 & 44.4 & 54.7 & 56.0 & 56.0 \\
\hline Significant increase & 0.0 & 0.0 & 0.0 & 0.0 & 0.0 & 0.0 & 1.3 & 0.0 & 0.0 \\
\hline
\end{tabular}

Table 1. Percent of streamflow gaging stations indicating significant $(p \leq 0.05)$ trends in winterspring center-volume date (WSCVD) and winter-spring streamflow volume (WSV) for three time periods tested under three assumptions of the time series data structure: independence (INDE), short term persistence (AR1), and long term persistence (LTP). "No change" in WSCVD indicates $\leq 2$ day change. Totals less than or greater than 100.0 are due to rounding. 


\begin{tabular}{|c|c|c|c|c|c|c|}
\hline \multirow[b]{2}{*}{ Months } & \multicolumn{3}{|c|}{ Percent significant } & \multicolumn{3}{|c|}{ Mean r-value } \\
\hline & EAST & WEST_H & WEST_L & EAST & WEST_H & WEST_L \\
\hline Jan & 16.7 & 0.0 & 47.4 & -0.28 & $N C$ & -0.38 \\
\hline $\mathrm{Feb}$ & $\underline{66.7}$ & 0.0 & $\underline{42.1}$ & -0.31 & $N C$ & -0.48 \\
\hline Mar & 100.0 & $\underline{61.5}$ & $\underline{100.0}$ & -0.55 & -0.37 & -0.50 \\
\hline Apr & $\underline{100.0}$ & $\underline{100.0}$ & $\underline{78.9}$ & -0.50 & -0.62 & -0.41 \\
\hline May & 36.7 & 100.0 & $\overline{63.2}$ & -0.29 & -0.53 & -0.35 \\
\hline June & $N T$ & $\underline{88.5}$ & $\underline{57.9}$ & $N T$ & -0.46 & -0.27 \\
\hline July & NT & $\overline{38.5}$ & $\overline{36.8}$ & $N T$ & -0.31 & -0.27 \\
\hline
\end{tabular}

Table 2. Percent of streamflow gaging stations with significant $(\mathrm{p} \leq 0.05)$ correlations between winter-spring center-volume date (WSCVD) and selected monthly air temperatures, 1940-2014. Mean r-values are computed on the basis of significant correlations only. Underlined percentsignificant values indicate field significance of correlations $(\mathrm{p} \leq 0.05)$ and bold mean $\mathrm{r}$-values indicate $\geq 50$ percent of stations had significant correlations. [EAST, all eastern gages $(n=30$, Figure 1, purple), WEST_H, high-elevation western gages $(\mathrm{n}=26$, mean basin elevation $>1,600$ m; Figure 1, blue); WEST_L, low-to-medium-elevation western gages ( $\mathrm{n}=19$, mean basin elevation $\leq 1,600 \mathrm{~m}$; Figure 1, red); NT, not tested as WSCVD period in East was defined as January-May; NC, not computed because of no significant correlations]. 


\begin{tabular}{|c|c|c|c|c|c|c|}
\hline \multirow[b]{2}{*}{ Months } & \multicolumn{3}{|c|}{ Percent significant } & \multicolumn{3}{|c|}{ Mean r-value } \\
\hline & EAST & WEST_H & WEST_L & EAST & WEST_H & WEST_L \\
\hline Jan & $\underline{50.0}$ & $\underline{76.9}$ & $\underline{26.3}$ & -0.30 & 0.32 & -0.08 \\
\hline $\mathrm{Feb}$ & $\overline{6.7}$ & $\overline{11.5}$ & $\overline{21.1}$ & 0.00 & 0.27 & -0.30 \\
\hline Mar & 13.3 & $\underline{57.7}$ & 10.5 & 0.27 & 0.34 & 0.26 \\
\hline Apr & $\underline{26.7}$ & $\underline{69.2}$ & 5.3 & 0.23 & 0.40 & -0.32 \\
\hline May & $\underline{13.3}$ & $\underline{61.5}$ & 10.5 & 0.33 & 0.37 & 0.26 \\
\hline June & $\overline{N T}$ & $\underline{69.2}$ & $\underline{21.1}$ & $N T$ & 0.32 & 0.31 \\
\hline July & $N T$ & 3.8 & 0.0 & $N T$ & 0.25 & NC \\
\hline
\end{tabular}

Table 3. Percent of streamflow gaging stations with significant $(\mathrm{p} \leq 0.05)$ correlations between winter-spring center-volume date (WSCVD) and selected monthly precipitation, 1940-2014. Mean r-values are computed on the basis of significant correlations only. Underlined percentsignificant values indicate field significance of correlations $(\mathrm{p} \leq 0.05)$ and bold mean $\mathrm{r}$-values indicate $\geq 50$ percent of stations had significant correlations. [See Table 2 for definitions]. 


\begin{tabular}{|c|c|c|c|c|c|c|c|}
\hline & \multirow[b]{2}{*}{ Months } & \multicolumn{3}{|c|}{ Percent significant } & \multicolumn{3}{|c|}{ Mean r-value } \\
\hline & & EAST & WEST_H & WEST_L & EAST & WEST_H & WEST_L \\
\hline \multirow{7}{*}{ 음 } & Jan & 13.3 & 15.4 & 47.4 & -0.29 & -0.27 & -0.36 \\
\hline & $\mathrm{Feb}$ & 36.7 & $\underline{23.1}$ & 84.2 & -0.31 & -0.18 & -0.45 \\
\hline & Mar & 33.3 & $\underline{15.4}$ & $\underline{89.5}$ & -0.29 & 0.15 & -0.42 \\
\hline & $A p r$ & $\underline{36.7}$ & $\underline{26.9}$ & $\underline{100.0}$ & -0.33 & -0.23 & -0.49 \\
\hline & May & 36.7 & $\underline{30.8}$ & $\underline{94.7}$ & -0.29 & -0.25 & -0.52 \\
\hline & June & $N T$ & $\underline{26.9}$ & $\underline{89.5}$ & $N T$ & -0.23 & -0.42 \\
\hline & July & $N T$ & 26.9 & 100.0 & $N T$ & -0.22 & -0.46 \\
\hline \multirow{7}{*}{$\overline{\mathbf{\Sigma}}$} & Jan & 10.0 & $\underline{26.9}$ & $\underline{68.4}$ & -0.27 & -0.04 & -0.35 \\
\hline & $\mathrm{Feb}$ & 23.3 & $\overline{23.1}$ & $\overline{68.4}$ & -0.27 & 0.11 & -0.37 \\
\hline & Mar & 33.3 & $\underline{26.9}$ & 84.2 & -0.29 & -0.04 & -0.42 \\
\hline & $A p r$ & 43.3 & $\underline{30.8}$ & $\underline{84.2}$ & -0.29 & -0.26 & -0.41 \\
\hline & May & 46.7 & $\overline{23.1}$ & $\overline{89.5}$ & -0.28 & -0.27 & -0.42 \\
\hline & June & $N T$ & $\underline{19.2}$ & $\underline{89.5}$ & $N T$ & -0.35 & -0.41 \\
\hline & July & $N T$ & 19.2 & $\underline{89.5}$ & $N T$ & -0.31 & -0.37 \\
\hline \multirow{7}{*}{ 운 } & Jan & 0.0 & 0.0 & 0.0 & $N C$ & $N C$ & $N C$ \\
\hline & $\mathrm{Feb}$ & 0.0 & 19.2 & 0.0 & $N C$ & -0.29 & $N C$ \\
\hline & Mar & 0.0 & 0.0 & 26.3 & $N C$ & $N C$ & -0.30 \\
\hline & Apr & 3.3 & $\underline{61.5}$ & 5.3 & 0.29 & -0.33 & -0.32 \\
\hline & May & $\underline{53.3}$ & 42.3 & 5.3 & 0.30 & -0.29 & -0.25 \\
\hline & June & $N T$ & 0.0 & 0.0 & $N T$ & $N C$ & $N C$ \\
\hline & July & $N T$ & 0.0 & 0.0 & $N T$ & $N C$ & $N C$ \\
\hline \multirow{7}{*}{$\sum_{<}^{0}$} & Jan & 3.3 & 7.7 & 5.3 & 0.25 & -0.29 & 0.26 \\
\hline & $\mathrm{Feb}$ & 0.0 & 0.0 & 5.3 & $N C$ & $N C$ & 0.27 \\
\hline & Mar & 10.0 & 3.8 & 0.0 & -0.28 & 0.25 & $N C$ \\
\hline & Apr & $\underline{13.3}$ & 3.8 & 0.0 & -0.34 & 0.25 & $N C$ \\
\hline & May & $\underline{66.7}$ & 0.0 & 0.0 & -0.33 & $N C$ & $N C$ \\
\hline & June & $N T$ & 15.4 & 10.5 & $N T$ & -0.27 & 0.01 \\
\hline & July & $N T$ & 15.4 & 10.5 & $N T$ & -0.29 & -0.02 \\
\hline
\end{tabular}

Table 4. Percent of streamflow gaging stations with significant $(\mathrm{p} \leq 0.05)$ correlations between winter-spring center-volume date (WSCVD) and selected ocean-atmosphere indices, 1940-2014. Mean r-values are computed on the basis of significant correlations only. Underlined percentsignificant values indicate field significance of correlations $(\mathrm{p} \leq 0.05)$ and bold mean $\mathrm{r}$-values indicate $\geq 50$ percent of stations had significant correlations. [PDO, Pacific Decadal Oscillation; 
MEI, Multivariate El-Nino/Southern Oscillation Index; NAO, North-Atlantic Oscillation; AMO, Atlantic Multi-Decadal Oscillation; see Table 2 for other definitions]. 
Figure 3

$Q C$

ND

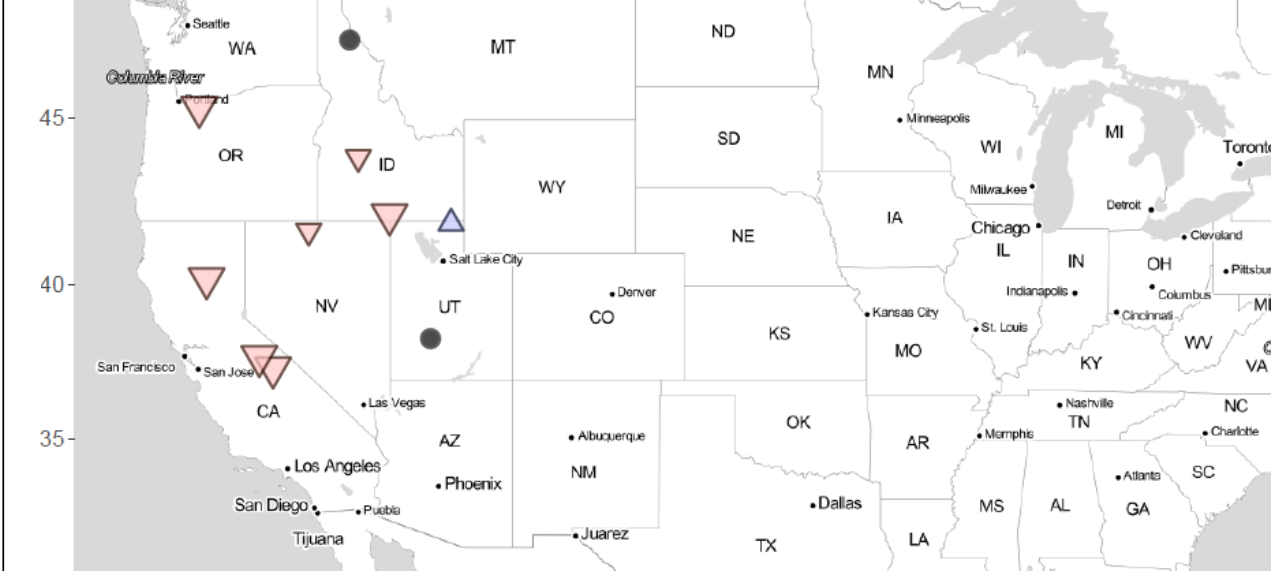

a $1920-2014$

- Chinustua San Antonio $^{\cdot H}$
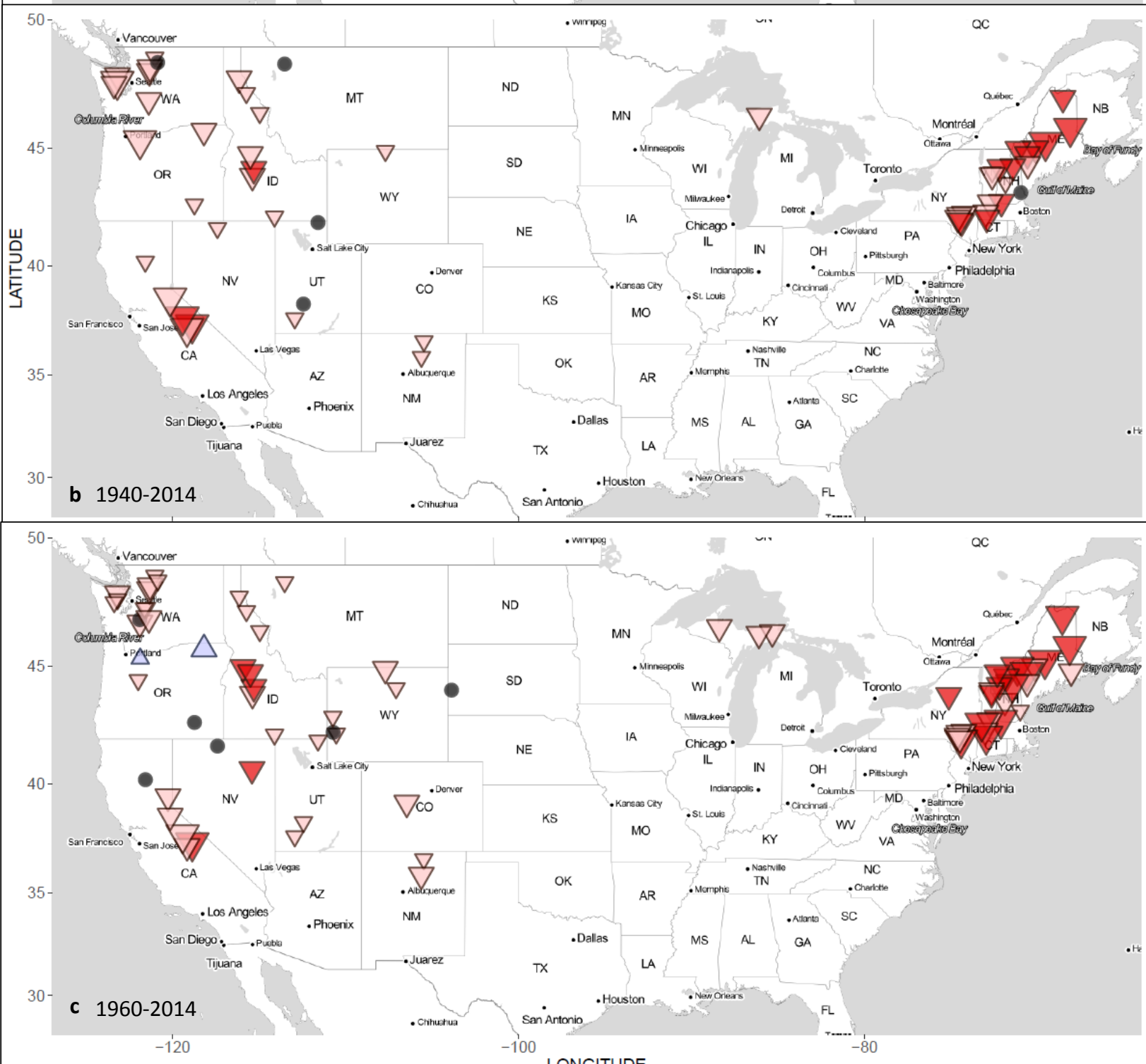

$-120$

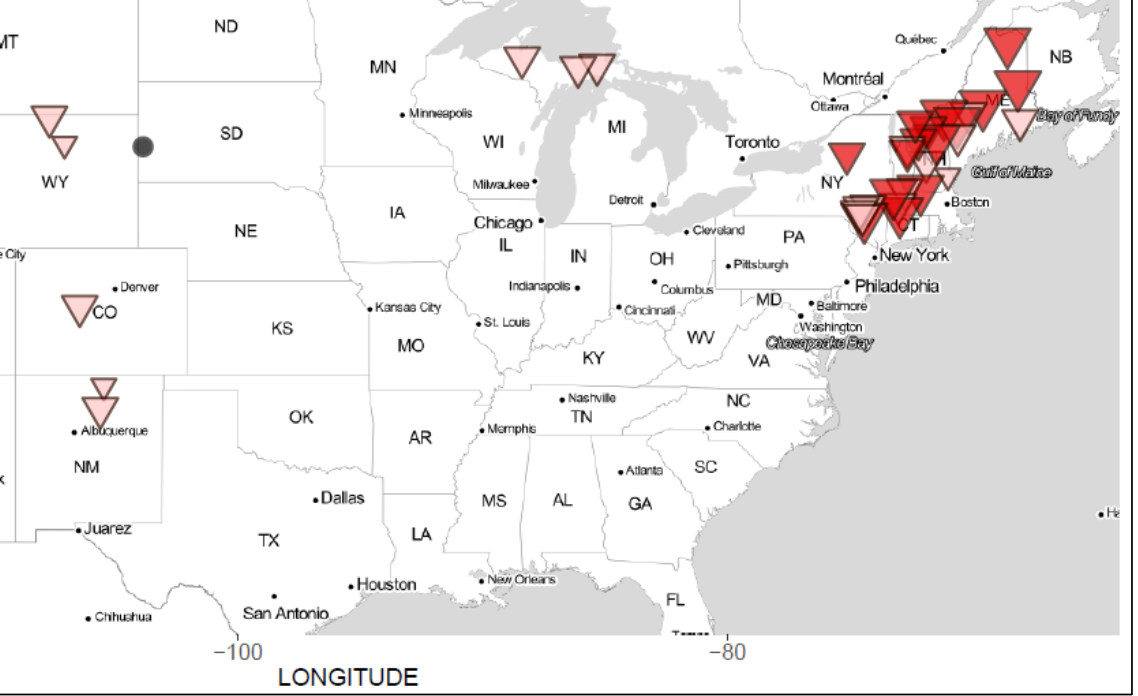

$\nabla \quad \nabla \quad \nabla \quad \bullet \quad \triangle \quad \triangle \triangle$

$>10$ days $>5$ and $\leq 10>2$ and $\leq 5 \leq 2$ days earlier $>2$ and $\leq 5>5$ and $\leq 10>10$ days

earlier days earlier days earlier or later dayslater dayslater later 


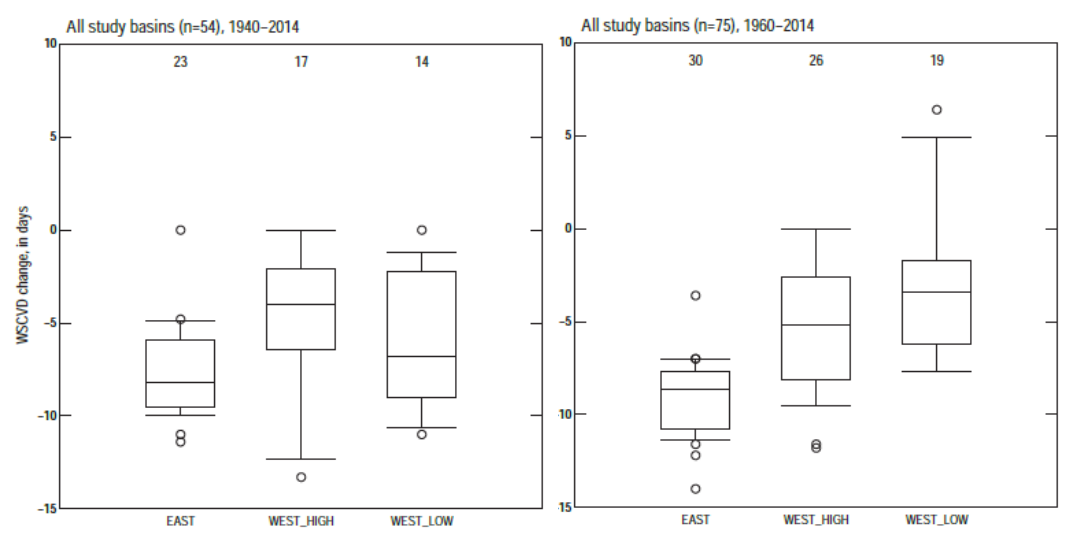

Figure 4

\section{Fure 4}

$$
\text { war wastan }
$$

$$
\text { (2) }
$$

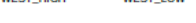




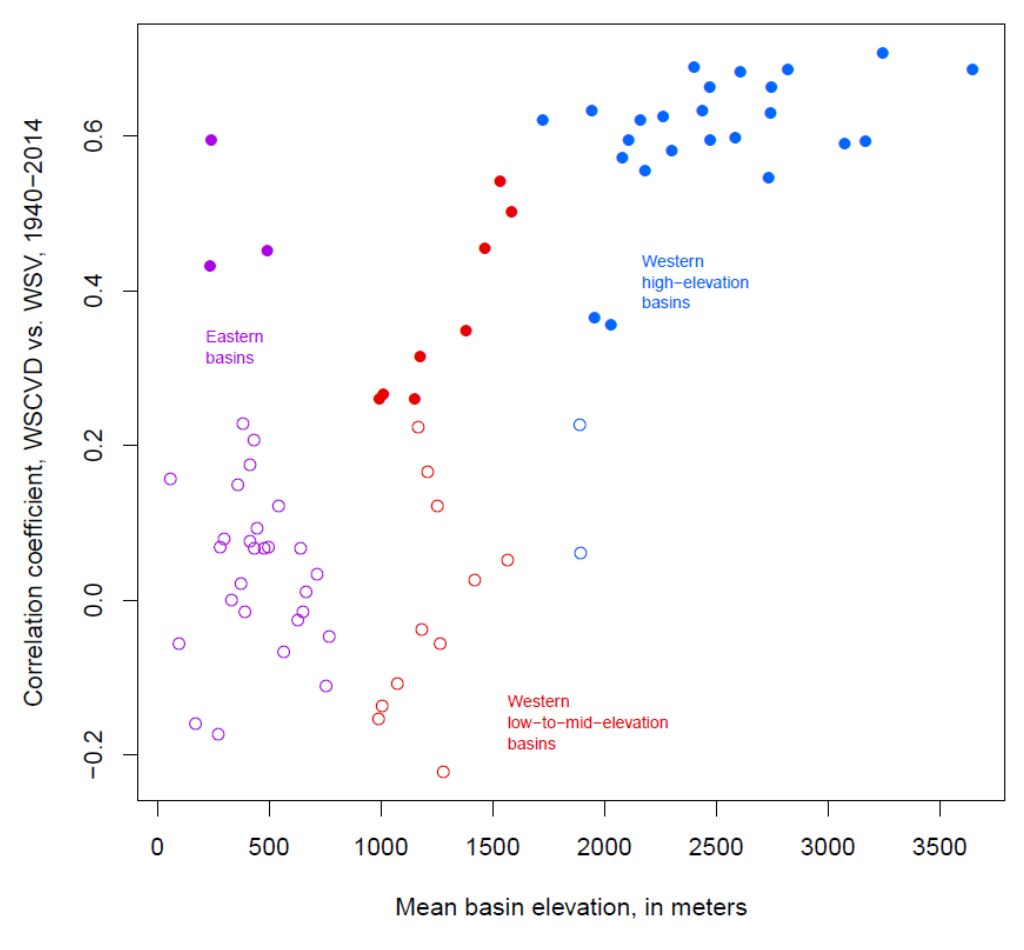

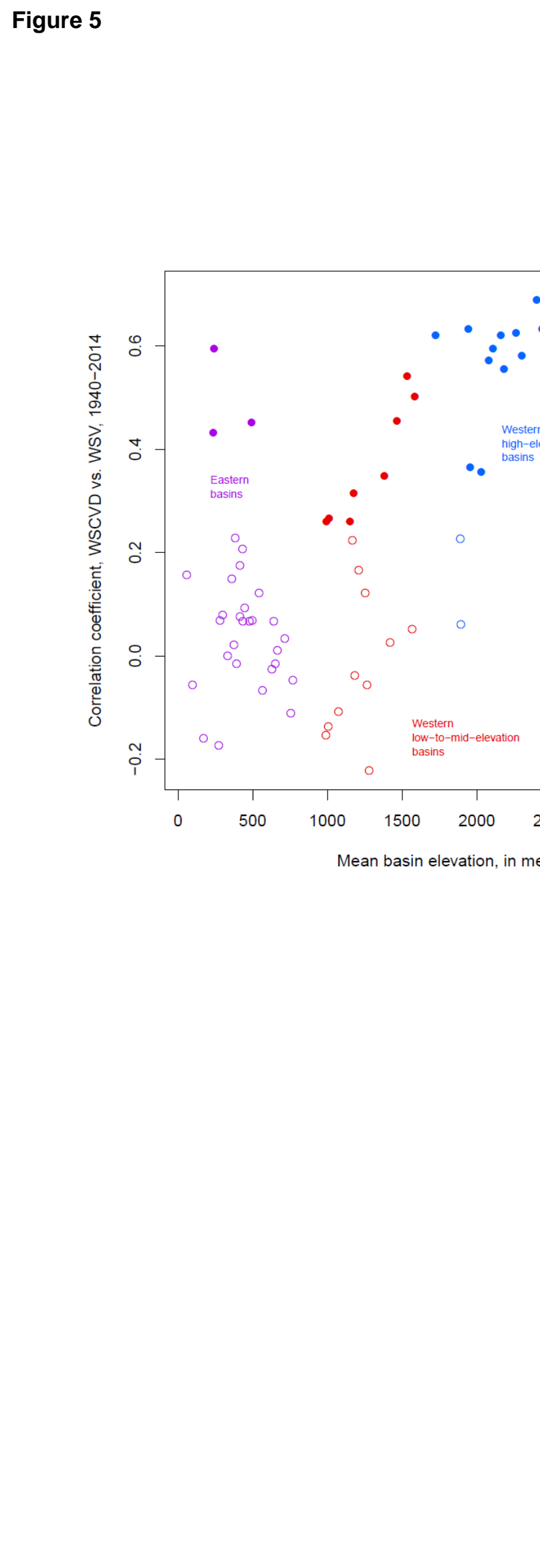

.

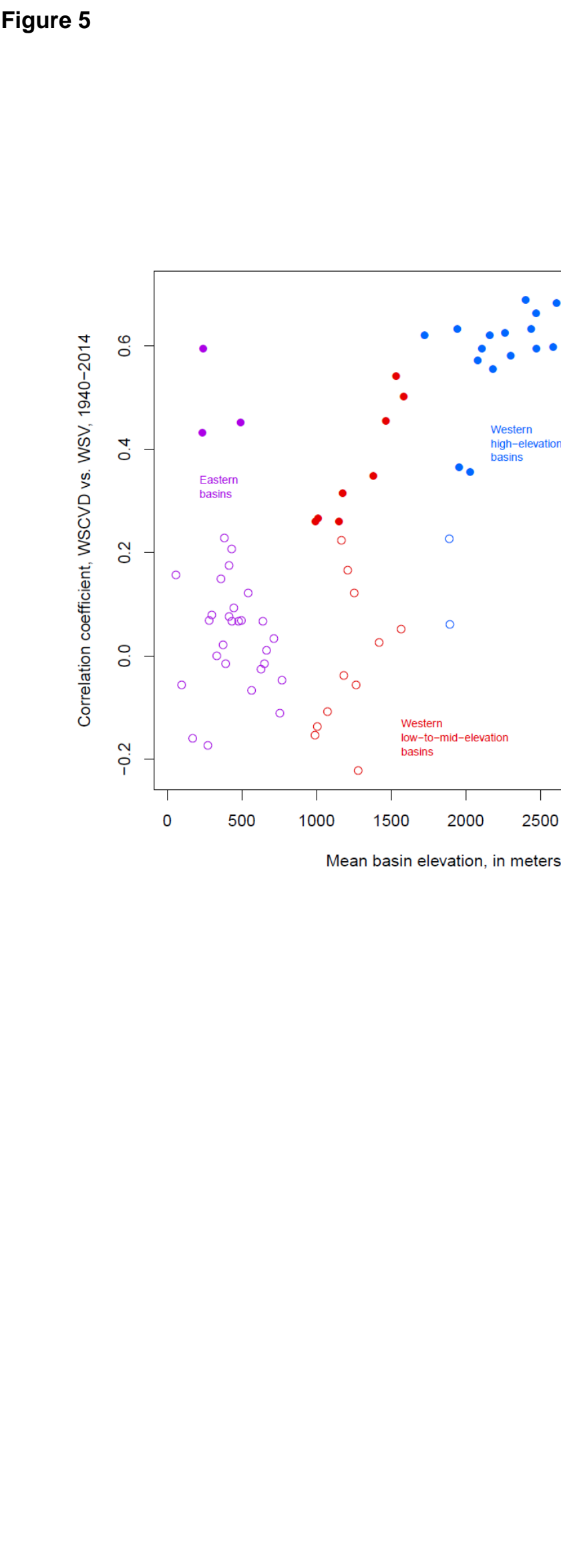




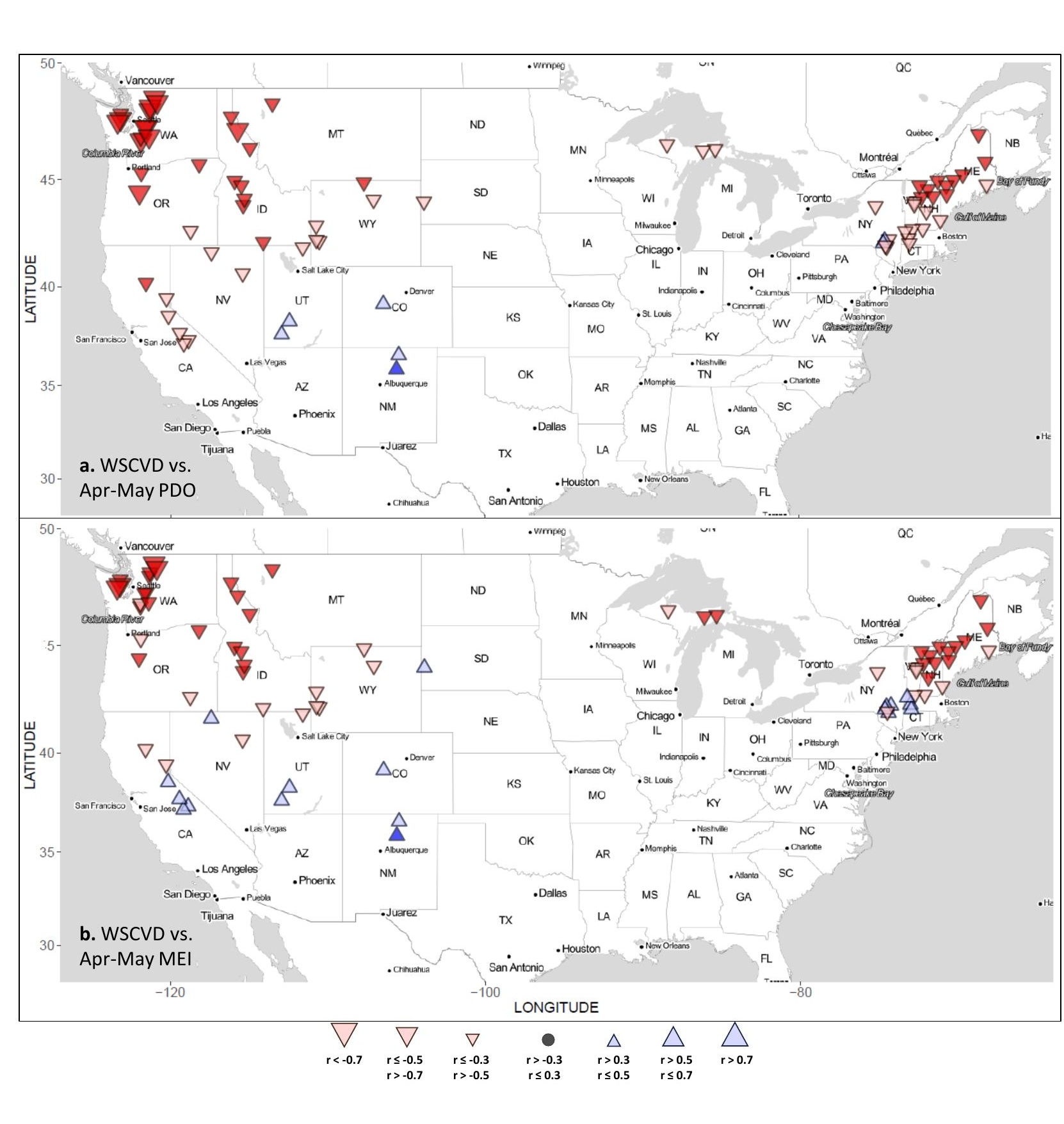

\section{Figure 6}
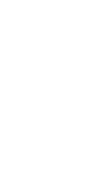

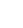




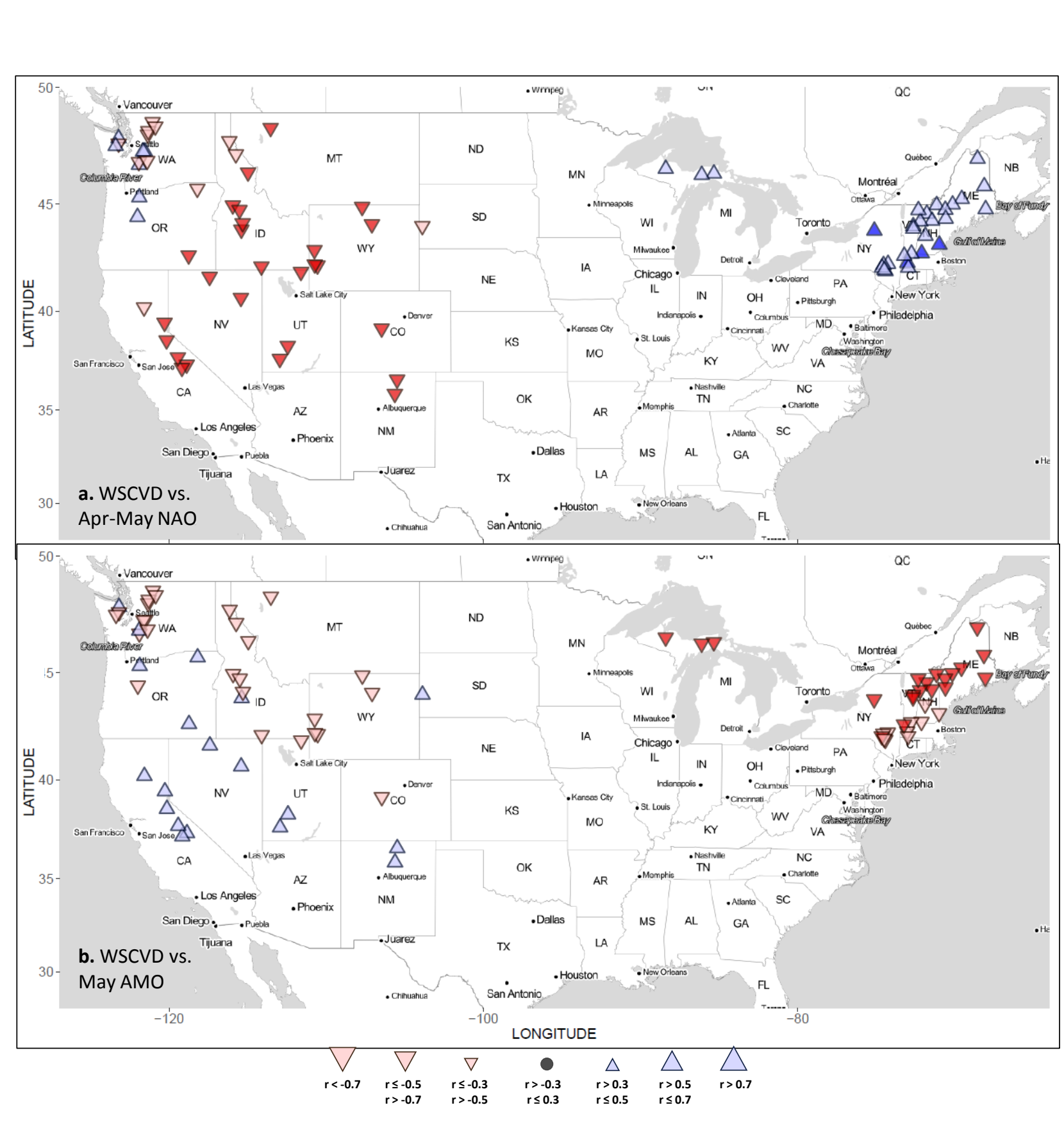

\section{Figure 7}

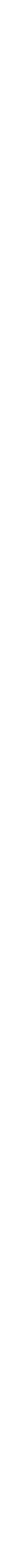



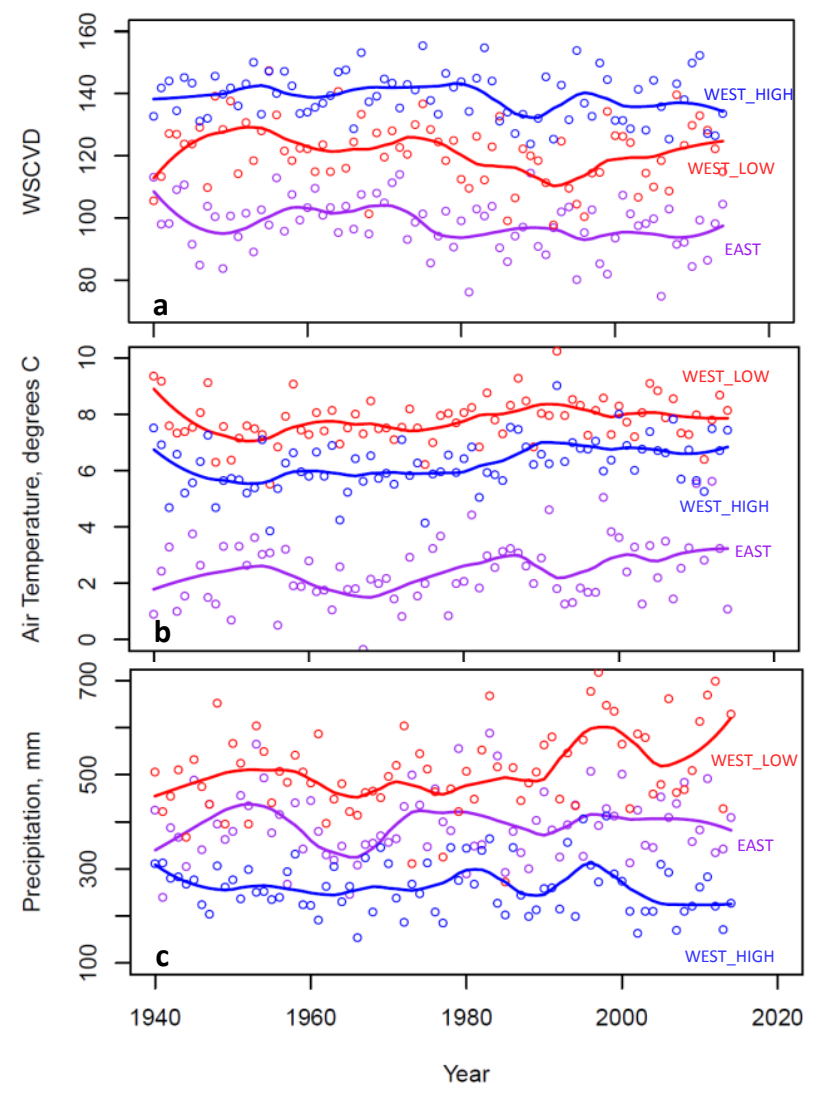